\title{
A Study on Increasing the Divorce Rate in Kerala
}

\author{
J. Godwin Premsingh ${ }^{1}$, Sheena Rajan Philip ${ }^{2}$ \\ ${ }^{I}$ (Associate Professor, Bishop Heber College, India) \\ ${ }_{2}^{2}$ (PhD Research Scholar, Bishop Heber College, India)
}

\begin{abstract}
Divorce is the dissolution of a social tie, but it is also possible that attitudes about divorce flow across social ties. The Researcher find that divorce can spread between friends, siblings, and coworkers, and there are clusters of divorcees that extend two degrees of separation in the network. We also find that popular people are less likely to get divorced, divorcees have denser social networks, and they are much more likely to remarry other divorcees. Interestingly, we do not find that the presence of children influences the likelihood of divorce, but we do find that each child reduces the susceptibility to being influenced by peers who get divorced. Overall, the results suggest that attending to the health of one's friends' marriages serves to support and enhance the durability of one's own relationship, and that, from a policy perspective, divorce should be understood as a collective phenomenon that extends far beyond those directly affected.
\end{abstract}

Keywords: Divorce, Kerla

\section{Introduction}

Every Coin has two sides and in same way marriage is one side and divorce is the opposite side of Coin. Divorce means separation of husband and wife from a legally solemnized marriage in a legally and customarily prescribed way by which both acquires a right to remarry again legally. In ancient India there was not existence of word divorce because according to Hinduism the marriage is a sacrament known as "Sanskara" through which both husband and wife tie up themselves with each other in a divine knot for present life and upcoming life. The term Divorce came in India with the advent of Muslim and given legal shape by the Colonial Rulers. The first law on divorce was framed by Whitely Stokes. The Bill, after remaining for seven years before the Council of the Governor-General, received the assent of the Governor-General, on 26 February 1869 i.e. The Indian Divorce Act 1869 which later amended in 2001 through The Indian Divorce (Amendment) Act 2001. Once, India used to have one of the lowest divorce rates in the world. Being a society largely based on a traditional value system, couples were both legally and socially dissuaded from seeking a divorce. However, socio-economic changes complemented by legal reforms in the last half a century, have enabled partners, especially women, to opt out of unequal and abusive marriages.

The wave of globalization in the nineties ushered in further changes in the Indian social institutions, especially in urban areas. Couples living and working in cities and metros, were exposed to more economic and relationship options, which prompted them to break out of unsatisfactory or unequal marriages. However, the divorce procedure in India continues to be one of the most protracted in the world, especially in cases where either party contests the divorce.

\section{Divorce Under Various Acts}

Divorce is the legal dissolution of marriage. Since India is a land of varied religious communities having their own marriage laws, the divorce procedure too varies, according to the community of the couple seeking divorce. All Hindus as well as Buddhists, Sikhs and Jains can seek divorce under the Hindu Marriage Act 1955. The Muslim, Christian and Parsi communities, on the other hand, have their own laws governing marriage and divorce. Spouses belonging to different communities and castes can seek divorce under the Special Marriage Act, 1956. There is also the Foreign Marriage Act 1969, governing divorce laws in marriages where either partner belongs to another nationality.

\section{Divorce By Mutual Consent}

Seeking a divorce in India is a long-drawn out legal affair, where the period of prosecution takes a minimum of six months. However, the time and money required to obtain a divorce can be considerably shortened if the couple seeks divorce by mutual consent. In this case, estranged spouses can mutually agree to a settlement and file for a "no-fault divorce" under Section 13B of the Hindu Marriage Act 1955. All marriages which have been solemnized before or after the Marriage Laws (Amendment) Act 1976, are entitled to make use of the provision of divorce by mutual consent. However, for filing for a divorce on this ground, it is necessary for the husband and wife to have lived separately for at least a year. 


\section{Review Of Study}

Beth anne Shelton (1980) in their book presented her analysis that paid work and household responsibilities not only impact on each other but may conflict. That is time spent in one sphere mean less time spent in another. If commitments to paid labour and household labour call for full time participants in both, that time must come either at the expense of leisure or else some of the demands of paid labour or household labour must go unmeant.

Deborach and Judith (1980) in their in book stated that their survey was designed to elicit response from both parents and non-parents on how they have reached decisions in their work family choices. For example, 85 percent of the 902 women believe that reducing hours of work is detrimental to women's career. Despite this widely held perception, 70 percent of the women with children decreased their hours of work after the birth of their first child. Knowing that the traditional rules of a male dominated work culture challenge their role as a parent, the Harvard women demonstrated a fierce determination to forge new definitions forbeing involved parent and a committed professional.

John Milton from 1643-1645 wrote during a period when thoughts about divorce were anything but simplistic; rather, there was active debate among thought-leaders. However, Milton's basic approval of divorce within strict parameters set by the biblical witness was typical of many influential Christian intellectuals, particularly the Westminster divines. Milton addressed the Assembly on the matter of divorce in August 1643, at a moment when the Assembly was beginning to form its opinion on the matter.

\section{Causes And Reasons}

There are many different and complex causes and reasons for divorce, each of them specific to that particular couple's marital relationship, their individual experiences, and personal problems. None of them may seem 'common' to the people going through a divorce, of course, but many of the reasons recur enough to warrant the term.

Several reasons have been cited that influence the act of getting a divorce. The following are certain common causes that have been listed.

Please note - The following reasons do not follow any particular order or ranking system; they have been listed in a random order.

- Infidelity

- Abuse in all forms (physical, sexual, emotional)

- Alcohol addiction and/or substance abuse

- Abandonment

- Personality differences or 'irreconcilable differences'

- Differences in personal and career goals

- Unemployment

- Financial problems

- Lack of communication between spouses

- Intellectual incompatibility

- Sexual incompatibility

- Falling out of love

- Religious conversion or religious beliefs

- Cultural and lifestyle differences

- Mental instability or mental illness in either partner

- Criminal behavior and incarceration for crime

- Lack of commitment to the marriage

- Inability to manage or resolve conflict

- Different expectations about household tasks

- Different expectations about having or rearing children

- Interference from parents or in-laws

- Lack of maturity

- Insistence of sticking to traditional roles and not allowing room for personal growth

- Inability to deal with each other's petty idiosyncrasies

- The lack of trust and/or feeling of insecurity 


\section{Major Findings}

As per the state government figures, between January 2011 and January 2012, the family courts in the state received 44,236 cases. The divorce cases of the last five years gives one an idea of where the state is headed for. The number was 8,456 in 2005-'06, 9,775 in 2006-'07, 9,937 in 2007-'08, 11,194 in 2008-'09, 11,600 in 2009- ' 10 and 24,815 in 2010-' 11 Thiruvananthapuram, the capital, leads with 6,000 cases. Kollam comes second (4,243), Thrissur (4,063), Kozhikode (4,008), Malappuram (3,934), Ernakulam (3,712), Kottayam $(2,880)$, Pathanamthitta $(2,044)$, Alappuzha $(2,361)$, Idukki $(1,161)$, Kasargod $(987)$, and Wayanad $(341)$.

\section{Conclusion}

As to conclude Human relationship education during the school years that provides skills in communication, problem solving and conflict resolution, and which encourages self-esteem, may also prepare young people for mature relationships as partners, parents and community members. Since relationships are dynamic and family circumstances alter over the life course (birth of a child, dealing with teenagers, a change in employment, illness of a family member), couples may benefit more from ongoing opportunities for a range of education and counselling options across the different stages of marriage and family life than from brief premarriage education sessions. A range of programs and services can be made available to develop understanding and skills in interpersonal relationship and parenting competence.

\section{References}

[1]. Centers for Disease Control (2007). MMWR Surveillance Summaries: Prevalence of Autism Spectrum Disorders - Autism and Developmental Disabilities Monitoring Network, 14 Sites, United States, 2002. Retrieved October 12, 2010, fromhttp://www.cdc.gov/mmwr/preview/mmwrhtml/ss5601a2.htm

[2]. Centers for Disease Control (2012). Prevalence of Autism Spectrum Disorders - Autism and Developmental Disabilities Monitoring Network, United States, 2008. Retrieved September 18, 2012 from http://www.cdc.gov/mmwr/pdf/ss/ss6103.pdf

[3]. American Psychiatric Association: Diagnostic and Statistical Manual of Mental Disorders, Fourth Edition, Text Revision. Washington, DC, Amercian Psychatric Association, 2000.

[4]. Gray, D.E. (2002). Ten years on: a longitudinal study of families of children with autism. Journal of Intellectual \& Developmental Disabilities, 27(3), 215-222.

[5]. Datz, T. (2006). Autism has high costs to U.S. society. Press release, April 25, 2006. Harvard School of Public Health. Retrieved October 14, 2010 from: http://www.hsph.harvard.edu/news/press-releases/2006-releases/press04252006.html

[6]. Doherty, S. (2008). Day-to-day struggles of autistic children affect entire family. The Capitol Times. Retrieved October 27, 2010 from: http://host.madison.com/ct/news/local/health_med_fit/article_c42f9884-2c8c-11df-be20-001cc4c002e0.html

[7]. Hartley, S. I., Barker, E. T., Seltzer, M. M., Floyd, F., Greenberg, J., Orsmond, G., et al. (2010). The relative risk and timing of divorce in families of children with an autism spectrum disorder. Journal of Family Psychology, 24(4), 449-457.

[8]. Kanner, L. (1943). Autistic disturbance of affective contact. American Journal of Psychiatry, 217-250.

[9]. Konstantareas, M. M. \& Stewart, K. (2006). Affective regulation and temperament in children with autism spectrum disorder.Journal of Autism and Developmental Disorders, 36(2), 143-154.

[10]. Kroeger, K.A., Schultz, J.R., \& Newsom, C. (2007). A comparison of two group-delivered social skills programs for young children with autism. Journal of Autism and Developmental Disorders, 37, 808-817. Altiere, M. J. \& von Kluge, S. (2009). Family functioning and coping behaviors 